\title{
Sosyal Bilgiler Öğretmen Adayları ile Yürütülen "Seçim" Odaklı Bir Medya Okuryazarlığı Uygulaması
}

\section{An "Election" Focused Media Literacy Application with Social Studies Teacher Candidates}

\author{
Nihal BALOĞLU UĞURLU*
}

\begin{abstract}
Öz: Bu araştırmanın amacı, medyanın Sosyal Bilgiler öğretmenlerinin seçim kararları üzerindeki etkililiğini test etmektir. Araştırmada, bu çalışma için aktif bir medya okuryazarı sorumluluğuna bürünen Sosyal Bilgiler öğretmen adayları, Kasım 2015 genel seçimleri öncesinde, farklı medya türlerinden ve medya ürünlerinden edindikleri haberleri farklı açılardan değerlendirmişler ve kendi siyasi kararlarını şekillendirmişlerdir. Araştırma 2015-2016 öğretim yılının Güz döneminde bir devlet üniversitesinin Eğitim Fakültesi Sosyal Bilgiler Öğretmenliği Anabilim Dalında öğrenim gören toplam 13 öğrenci ile birlikte yürütülmüştür. Araştırma nitel araştırma yöntemi ile gerçekleştirilmiş olup, Kasım 2015 seçimlerinin hemen öncesinde aktif bir medya okuryazarı sorumluluğu üstlenen Sosyal Bilgiler öğretmen adaylarının, seçim ile ilgili medya haberlerini edinmeleri sağlanmış ve sonrasında odak grup görüşmesi tekniği kullanılarak görüşleri alınmıştır. Araştırmada, öğretmen adaylarının medya tercihlerinin televizyon, internet ve gazete olduğu, siyasal söylemleri ön planda tuttukları, ajans haberlerini daha fazla tercih ettikleri, edindikleri haberlere eleştirel yaklaşabildikleri ve yorum yapabildikleri görülmüştür. Öğrencilerini demokratik toplumda aktif bir medya okuryazarı olarak eğitecek olan Sosyal Bilgiler öğretmen adaylarının, kendilerinin de bu davranışları gerçekleştirecek çeşitli medya okuryazarlığı programlarına dahil edilmelerinin faydalı olabileceği bu araştırmanın en önemli sonucudur. Anahtar Kelimeler: medya okuryazarlı̆̆, seçmen kararı, sosyal bilgiler ögrretmen adayları.
\end{abstract}

\begin{abstract}
The aim of this study was to test the effectiveness of media on Social Studies teacher candidates' election decisions. In this study, Social Studies teacher candidates who were actively media literate before November 2015 elections evaluated the news with various perspectives which shaped their political decisions. The study was conducted with thirteen Social Studies teacher candidates from a state university's Faculty of Education in the fall semester of 2015-2016 academic year. The study was configured with qualitative methods. Before actively media literate Social Studies teacher candidates began using the media their opinions were formed by focus group discussion. The results of this study were that the teacher candidates preferred television, internet and newspaper communication; they kept on top of political discourses ; they mostly absorbed news from news agencies ; they approached news critically and analytically and they were able to comment about news. Social Studies teacher candidates who will one day educate their students as active media literates in a democratic society should be exposed to different types of training programs in media literacy.
\end{abstract}

Key Words: Media literacy, voter decision, social studies teacher candidates.

\section{Giriş}

Toplumların demokrasiyi her geçen gün daha fazla içselleştirme çabası, alternatiflerin değerlendirilmesi ve farklı uygulamaların gerçekleştirilmesini beraberinde getirmektedir. Doğaldır ki, teknolojideki gelişmeler her alanda olduğu gibi demokrasi uygulamalarında da önemli bir rol oynar. Hiç kimse kitle iletişim araçlarında artık son noktaya varıldığı düşüncesinde olmadığından, demokratik bakış açısını yansıtmada teknoloji araçlarının kullanımının da daha farklı nasıl şekillenebileceği ile ilgili öngörülerini sınırlandıramamaktadır. $\mathrm{Bu}$ durum, demokratik toplumlarda yaşayan bireylerin kendi demokrasi anlayışlarını şekillendirmede kitle iletişim araçlarını en geniş yelpazede kullanmalarını gerektirmektedir (Üskül, 1993).

Demokrasinin en önemli göstergesi seçimlerdir. Halk, kendini yönetmesini arzu ettiği temsilcilerini seçimle işbaşına getirebilmeli ve iş başında iken de onları denetleyebilmeli ve

\footnotetext{
** Yrd. Doç. Dr., Ömer Halisdemir Ünv., Eğitim Fak., Niğde-Türkiye, nihalugurlu@nigde.edu.tr
} 
eleştirebilmelidir. Onların bir sonraki seçimlerde yeniden iktidar olabilmelerini sağlamak için gerektiğinde onlara uyarıda bulunabilmeli, vatandaşlık haklarının ihlal edildiği düşüncesine sahip olduklarında iktidardan haklarının iadesini isteyebilmelidir. Bütün bu paylaşımlar ise özgür düşünce yapısına ve ifade serbestliğine imkân sağlayan, kişi hak ve özgürlüklerinin en geniş bir şekilde uygulanabildiği demokrasi sisteminin basın özgürlüğü çerçevesinde gerçekleştirilebilmelidir (Gezgin, 2006). Nitekim medyanın özgür olmadığı bir ülkede demokrasiden söz edilemeyeceği bir gerçektir (Yazıcı, 2014). Medya organlarının sürecin bir parçası olduğu siyasal iletişim, demokrasinin sağlıklı bir şekilde işleyebilmesinin teminatıdır.

\section{Siyasal İletişim ve Medya}

Medya organları ve siyasi kurumlar, toplum tarafindan görevlendirilen ve topluma hizmet eden asıl unsurlardandır. Siyasal iletişim ise, doğrudan medyayı adres gösteren ve siyasetçiler ile toplum arasındaki bilginin medya aracılığı ile paylaşımını gerçekleştiren bir süreçtir. Bu süreçte bilginin, siyasetçiden bireye doğru aşağı yönlü ya da bireyden siyasetçiye doğru yukarı yönlü bir aktarımı söz konusudur (Çağlar ve Özkır, 2015). Aşağı yönlü aktarımlarda siyasetçiler medyayı bir reklam ya da propaganda aracı olarak kullanırken, yukarı doğru aktarımlarda ise toplum tarafından sosyal medya aracılığı ile paylaşılan, siyasi konulara ilişkin mesajlar ve kamuoyu yoklamaları söz konusudur. Medyanın yapılandırdığı siyasal iletişimde toplum tarafından benimsenen yaygın görüş siyasal görüşü de şekillendirecektir. Bu nedenle medya, demokratik bir toplumda birtakım sorumlulukları üstlenmek durumundadır. Bu sorumluluklar, toplumu tam ve doğru bir şekilde eğitmek ve bilgilendirmek, taraflı kaynakları özellikle de hükümet ve muhalefet partileri tarafından ortaya atılan iddiaları bağımsız bir şekilde araştırmaktır (Kenterelidou, 2005). Böylece, toplumun siyasal sisteme karşı ilgi ve bilinçlilik düzeyinin artması, bu ilgi ve bilincin oy vermek gibi en basit düzeydeki siyasal davranışlara bile yansıması hem demokrasinin işlevsel ve anlamlı bir hale dönüştürülmesine neden olacak (Dilber, 2012) hem de demokratik toplumlarda yerini alacak olan sorumlu vatandaşlığın ön koşulu gerçekleştirilmiş olacaktır (Bilici, 2012).

Siyasal iletişimde medyanın bir diğer fonksiyonelliği, gerçekleştirdiği iletişim sürecinde siyasetçiler ile vatandaşlar arasındaki sosyal mesafeyi azaltmasıdır. Medya sayesinde bireyler, erişimlerinin mümkün olmadığı birtakım siyasal süreçleri kavrayabilirler. Bununla birlikte, medyanın siyasal aktörleri mercek altına alması, onların aldıkları kararları ve gerçekleştirdikleri eylemleri çok yakından takip etmesi ve onları topluma "içimizden biri" gibi sunması, siyasetçilerin toplum tarafından yakınlarında ve ulaşılabilir olarak algılanmalarına neden olur (Çebi, 2002). Bu durum, bireylere, birtakım demokratik haklarını kullanırken olumlu bir şekilde yansımaktadır. Seçim dönemlerinde halk oy vereceği partinin liderini daha yakından takip etme ihtiyaci duyar.

\section{Medyanın Bireyin Siyasi Kararlarında Etkililiği}

Demokratik toplumlarda siyasi karar alıcıları olarak bireylerin siyasal görüşlerinin şekillenmesinde medyanın önemi büyüktür. Medya topluma ne kadar çok bilgi aktarımını gerçekleştirirse bireyler o kadar çok şey öğrenirler. $\mathrm{Bu}$ manada, medya aracılığı ile gerçekleştirilen seçim kampanyaları aslında bir kamu hizmetidir (Apospori, Avlonitis ve Zisouli, 2010). Toplumdaki bireylerin özellikle de seçim gibi demokratik süreçlerde medya tarafından bilgilendirilmeleri ve medyayı takip ederek siyasilerin görüş ve faaliyetlerinden haberdar olmaları, onların kendi kanaatlerini oluşturmada ve düşüncelerini yapılandırmalarında etkilidir (Arklan ve Karakoç, 2013).

Medyanın bireylerin siyasi görüşlerini şekillendirmesinde, bireyin medyaya olan güveni de önemlidir. Toplumun, medyanın yansız ve objektif olduğuna yönelik algısı, aralarında düzenli bir ilişkinin kurulması ve yürütülmesini mümkün kılar. Tam tersine toplumun belirli bir kesiminde, herhangi bir medya organının yanlı haber sunması ile ilgili bir kanaat oluştuğunda, o medyanın inandırıcılığını kaybetmesi kaçınılmazdır (Güz, 2005, Akt. Akdağ, 2014). Medya organının kendisi kadar verdiği mesajın kaynağı da güvenilirliği etkileyen bir başka faktördür. 


\section{BALOĞLU UĞURLU}

Medyanın yansıttığı mesajlar, alanında otorite ve güvenilir kaynaklara dayanıyorsa, güvenilirliği ve toplum üzerinde etkili olma derecesi daha yüksek olarak görülebilmektedir (Arslan, 2002).

Bireylerin siyasal sistemlere ve olaylara bakış açılarını doğrudan medya ile ilişkilendirmek de doğru değildir. Her ne kadar medyadan bireye bir iletim söz konusu ise de bireyin bu iletim karşısında aktif olması, iletim sürecini etkileşim sürecine dönüştürebilmektedir. Bireyin aktifliğinin en önemli göstergesi ise medyanın kullanımı ile ilgili bilinçliliğinin üst düzeyde olmasıdır. Medya okuryazarlığı kavramı çerçevesinde ele alınan bu konu, medyanın herhangi bir ürününün karşısında pasif bir durumda olan bireyi aktifleştirmeye yönelik faaliyetleri kapsar. Nitekim medya gerçekliğin birebir yansımasını değil, temsilini sunar ve buna yaparken de gerçeği kasıtlı ya da kasitsız şekilde yeniden kurar. Bu durumda bireyin yapması gereken ilk şey, medya mesajlarını iletildiği hali ile kabul etmemek, alınan mesajları aktif bir düşünme ve sorgulama sürecinden geçirmektir. İkinci aşamada ise birey, bu süreçte kavranılan işleyişlerin doğasını uygulama yolu ile pekiştirmelidir (Çetinkaya, 2008). Böylece birey, medya okuryazarlığının eleştirel düşünme, problem çözme, ifade etme, iletişim ve etkileşim kurma ile sivil katılım ve aktif vatandaşlık boyutlarını gerçekleştirmede önemli bir yol katetmiş olur (Tornero ve Varis, 2010).

\section{Medya Okuryazarlığı, Sosyal Katılım ve Sosyal Bilgiler}

Sosyal Bilgiler dersi tanımlanırken kullanılan "sosyal katılım becerileri gelişmiş" ve "sosyal yaşamda etkin, üretken, haklarını ve sorumluluklarını bilen vatandaş" ifadeleri (MEB, 2005, 45), evrensel anlamda medya kültürünü özümsemiş, medya okuryazarlığının demokrasiyi içselleştirmiş bireylerinin gerçekleştirmiş olduğu eleştirel düşünme ve kendini ifade etme becerileri ile birebir örtüşmektedir. Medya okuryazarlı̆̆ programı ile amaçlanan, bireylerin, kamusal söylemleri anlamasına ve katkıda bulunmasına imkân tanımak ve nihayetinde onların bilinçli olarak kendi siyasal kararlarını almalarına destek olmaktır (Thoman vd. 2003) Böylece, medya okuryazarlığı eğitimi, vatandaşlık bilincini geliştirme hedefini gerçekleştirmiş olur (Bilici, 2014). Kendi mesajlarını üretebilen ve ifade edebilen bireylerin, siyasal, sosyal ve ekonomik hayatta daha aktif bir şekilde yer alacakları açıktır (Altun, 2009).

Son yıllarda kitle iletişim araçlarının bireylerin üzerindeki olumlu ve olumsuz etkilerinin daha sık tartışılmaya başlanması ve bu nedenle medyanın bilinçli kullanımının erken yaşlardan itibaren başlama gerekliliği, Milli Eğitim Bakanlığı'nı medya okuryazarlığı konusu ile ilgili harekete geçirmiştir. 2006 yılında yapılan bir düzenleme ile Medya Okuryazarlığ dersi ilköğretim 7. Sınıf dersi olarak okutulmaya başlamıştır. Ancak medya okuryazarlığını sadece bir ders alanı olarak görmek doğru değildir. Medya okuryazarlığı, siyasi, sosyal ve ekonomik konuların yer aldığı Sosyal Bilgiler derslerinde de üzerinde durulması gerekli bir konudur. Bu nedenle bu araştırma, Sosyal Bilgiler ders içeriğinin ayrılmaz bir parçası olan medya okuryazarlığının siyasi kararlar alabilme yetisine sahip aktif bir vatandaş olarak Sosyal Bilgiler öğretmen adayları tarafından ne düzeyde içselleştirildiğini tespit etmek ve onların medya kullanımları açısından kendi bakış açılarını yansıtmak üzere yapılandırılmıştır. Araştırmada, Kasım 2015 genel seçimleri öncesinde, Sosyal Bilgiler öğretmen adaylarının aktif oldukları bu araştırma programı dâhilinde, araştırma grubunun ulaştıkları medya türünün ve medya ürününün, edindikleri haberin niteliğinin ve içeriğinin ve edindikleri haberlerle ilgili kişisel değerlendirmelerinin nicel olarak tespit edilmesi amaçlanmıştır. Ayrıca nitel olarak da onların medya kullanım alışkanlıklarının ortaya koyulması ve bu süreç ile ilgili düşüncelerinin neler olduğunun tespiti hedeflenmiştir.

\section{Yöntem}

$\mathrm{Bu}$ bölümde araştırma modeli, çalışma grubu, veri toplama aracı, verilerin çözümlenmesi başlıklarına yer verilmiştir.

\section{Araştırma Modeli}

$\mathrm{Bu}$ araştırma, nitel araştırma yöntemi ile yapılandırılmıştır. Araştırmanın nitel boyutu ile ilgili tespitlere geçmeden önce, aktif bir medya okuryazarı olarak seçim öncesi dönemde kendi siyasi 
kararlarını şekillendirmelerine yönelik bir programa dâhil edilen Sosyal Bilgiler öğretmen adaylarının, edindikleri haberleri değerlendirmeleri sağlanmıştır. Sonrasında ise nitel bir araştırma yöntemi olan odak grup görüşmesi yöntemi uygulanmış ve öğretmen adaylarının uygulama süreci sonrasındaki düşünceleri bu yöntem kapsamında değerlendirilmiştir. Odak grup görüşmesi, öğrencilerin kendilerini rahat hissettikleri bir ortamda bir konu ile ilgili algılamalarını öğrenmek amacıyla dikkatle planlanmış bir tartışmalar serisidir. Bu yöntemde çalışmaya dâhil edilen bireylerin mevcut konu ile ilgili ortak tecrübelerinin olmas1 gerekmektedir (Yıldırım ve Şimşek, 2006).

\section{Çalışma Grubu}

Çalışma grubunda yer alan öğretmen adayları, 2015-2016 öğretim yılının Güz döneminde bir devlet üniversitesinin Eğitim Fakültesi İlköğretim Bölümü Sosyal Bilgiler Öğretmenliği Anabilim Dalında öğrenim görmektedirler. Araştırma grubunda yer alan öğretmen adaylarının 10 gün süreli bir uygulama programına dâhil olmaları, hem onların aynı fakültenin öğrencileri olmalarına ve hem de bu araştırmaya gönüllü katılımları esasına dayandırılmalarına neden olmuştur. Araştırmada 9 kadın, 4 erkek olmak üzere toplam 13 Sosyal Bilgiler öğretmen adayı yer almaktadır.

\section{Veri Toplama}

Veri toplama yöntemi

$\mathrm{Bu}$ araştırmada öğretmen adaylarının medya okuryazarlığı ile ilgili farkındalıklarını artırmak ve bu farkındalıklarını siyasi kararlarına yansıtmak üzere bir uygulama süreci gerçekleştirilmiştir. 2015 Kasım seçimlerinden önceki 10 gün süreli uygulama aşamasında, öğretmen adaylarının fakültenin bilgisayar laboratuvarında internet erişimleri sağlanmış ve ayrıca okumaları için çeşitli gazeteler de onlara tedarik edilmiştir. Öğretmen adaylarının televizyon ve radyoya ulaşımları da yine internet üzerinden ya da kendi yaşadıkları ortamlardan mümkün olabilmiştir. Öğretmen adaylarının bu medya organlarına ulaşımları ve sadece seçim ile ilgili haberlere odaklanmaları istenmiştir. Bu haberler ile ilgili olarak da araştırmanın veri toplama aracından biri olan haber değerlendirme formundaki mevcut maddeleri işaretlemeleri için yönlendirilmişlerdir.

Ölçme aracı

Araştırmada öğretmen adaylarının edindikleri habere ilişkin sayısal verileri elde etmek üzere bir "haber değerlendirme formu" kullanılmıştır. Araştırmacı tarafından alanyazın taraması destekli geliştirilen bu formun içeriğinde, medya okuryazarı özelliklerine uygun olarak, öğretmen adaylarının haberi edindikleri medya türü ve medya ürünü, edindikleri haberin niteliği ve içeriği ve haberin onlara göre gerçekliği, eleştirel ve yorumsal olma gibi çeşitli kriterler ile ilgili düşüncelerini öğrenmeye yönelik maddeler yer almaktadır. Bu formda yer alan sorular, araştırma grubunun tutum ve davranışlarını veya araştırma konusu ile ilgili öznel görüşlerini elde etmekten ziyade, sayılarla ifade edilebilecek nitelikte ve edinilen haberle ilgili tanıtıc1 verilerden oluştuğu için, geçerlik ve güvenirlik analizine gereksinim duyulmamıştır.

Araştırmanın nitel boyutunda ise araştırma grubu ile odak grup görüşmesi yapılmıştır. $\mathrm{Bu}$ görüşmede açık uçlu sorulardan oluşan yarı-yapılandırılmış odak grup görüşme formu kullanılmıştır. Bu formda yer alan sorular, alanyazın taraması da yapılarak, araştırmacı tarafından geliştirilmiş olup, etkili bir medya okuryazarlığı sürecini yaşamış ve bunun sonucunda da seçim döneminde kendisi açısından en doğru kararı verdiği kanısına varmış bir bireyin görüşlerini elde etmeyi hedeflemektedir.

\section{Verilerin Çözümlenmesi}

Araştırmada, haber değerlendirme formundan elde edilen veriler SPSS 16.0 istatistik programında yüzde ve frekans değerleri hesaplanarak kullanılmıştır. Odak grup görüşmesinden elde edilen veriler ise sayısallaştırılmamıştır. Nitekim Fern (2001) ve Suler (1995) odak grup görüşmelerinde genelleme kaygısı olmadığından, elde edilen verilerin istatistiksel tablolar haline dönüştürülmesine gerek olmadığı, bir başka deyişle sayısallaştırılmaması gerektiğini 


\section{BALOĞLU UĞURLU}

ifade etmektedirler (Akt. Çokluk, Yılmaz ve Oğuz, 2011). Bu nedenle öğretmen adaylarından elde edilen sözel ifadeler üzerinde hiçbir değişiklik yapılmadan çalışmaya aktarılmıştır.

\section{Bulgular}

$\mathrm{Bu}$ bölümde, Sosyal Bilgiler öğretmen adaylarının edindikleri her haberle ilgili olarak doldurmuş oldukları haber değerlendirme formundan elde edilen sayısal verilere ve onların odak grup görüşmesinde yarı-yapılandırılmış sorulara verdikleri sözlü ifadelere yer verilmiştir.

Ö̆̆retmen adaylarının medya dĕgerlendirmeleri;

Araştırma grubunda yer alan öğretmen adaylarının haberlere ait medya değerlendirmeleri Tablo 1 'de yer almaktadır.

Tablo 1: Sosyal Bilgiler Öğretmen Adaylarının Edindikleri Haberlere Ait Medya Türleri ve Medya Ürünleri

\begin{tabular}{|c|c|c|c|c|c|c|c|}
\hline \multirow{2}{*}{$\begin{array}{c}\text { Okuduğu } \\
\text { Haber } \\
\text { Sayıs1 }\end{array}$} & \multicolumn{4}{|c|}{ Habere Ait Medya Türü } & \multicolumn{3}{|c|}{ Haberin Medya Ürünü } \\
\hline & Gazete & İnternet & Televizyon & Radyo & $\begin{array}{l}\text { Ajans } \\
\text { Haberi }\end{array}$ & $\begin{array}{l}\text { Köşe } \\
\text { Yaz1s1 }\end{array}$ & $\begin{array}{l}\text { Tartışma } \\
\text { Progg. }\end{array}$ \\
\hline 306 & $\begin{array}{c}138 \\
(\% 45) \\
\end{array}$ & $\begin{array}{c}131 \\
(\% 43) \\
\end{array}$ & $\begin{array}{c}30 \\
(\% 10) \\
\end{array}$ & $\begin{array}{c}3 \\
(\% 1) \\
\end{array}$ & $\begin{array}{c}202 \\
(\% 66)\end{array}$ & $\begin{array}{c}78 \\
(\% 26) \\
\end{array}$ & $\begin{array}{c}21 \\
(\% 7) \\
\end{array}$ \\
\hline
\end{tabular}

Tablo 1'e göre Sosyal Bilgiler öğretmen adayları toplam 306 tane habere ulaşmıştır. Bu haberlerin $138(\% 45)$ 'i gazeteden, 131 (\%43)'i internetten, $30(\% 10)$ 'u televizyondan, ve 3 (\%1)'ü radyodan elde edilmiştir. Haberlerin medya ürünü olarak da 202 (\%66)'sinin ajans haberi, 78 (\%26)'sinin köşe yazısı ve 21 (\%7)'inin tartışma programı olduğu görülmektedir.

Öğretmen adaylarının siyasi gündemi takip ettikleri medya organını tercih nedenleri ile ilgili sözlü ifadelerinden bazıları şu şekildedir:

.....Genelde gazeteyi tercih ederim çünkü ben köşse yazılarını okumayı daha çok seviyorum ... ondan dolayı gazete tercih ediyorum (Ö5).

...Gazete ve televizyon diyorum. Eve sonuçta bir tane gazete aliniyor ve onu ben de okuyorum babamda okuyor ya da kardeşlerimde okuyor ve bir haber gördügü̈mde ben merak ettiğimde ya da bilgim yetersiz olduğunda tartışabiliyoruz, karşılıklı görüş alışverişi yapabiliyoruz en azından...(Ö2).

Ben haberlere daha çok internetten baklyorum. Hemen elimin altında o yüzden (Ö13).

Internet daha kolay geliyor....(Ö7).

Ben internet ve sosyal medya diyorum çünkü sosyal medyada daha fazla çeşitlilik var. Daha farkl görüşler var o yüzden sosyal medya (Ö8).

Daha çok internet üzerinden takip ediyorum. Çünkü diğer medya organlarında haberleşme özgürlügünün kısıtlandığını düşünüyorum...(Ö10).

Televizyondan takip ederim. Daha pratik çünkü görsel açıdan, daha fazla konular var...(Ö6).

Televizyonu tercih ederim. Televizyonda gündemi rahatllkla takip edebilirim...televizyonu açmak kanal değiştirmek daha kolay (Ö3).

Televizyonu ve interneti tercih ediyorum. Daha çok elimin altındalar. Mesela televizyondan farkl görüşleri yansitan kanallara ulaşabiliyorum ya da internetten farklı siteleri ziyaret edebiliyorum (Ö12).

Öğretmen adaylarının siyasi gündemden haberdar oldukları medya ürünü ile ilgili tercihlerini yansıtan ifadelerinin bazıları da aşağıdaki gibidir:

Ben ajans haberi diyorum.....Ajans haberinin kendime daha çok katkı sağladı̆̆ını düşünüyorum (Ö7). 
Ajans haberi diyorum. Çünkü tartışma programlarında ya da bir köşe yazısında herkes kendi düşüncesini söylüyor oysa ben kendi düşünceme önem verdiğim için sadece ajans haberine bakıp kendi düşüncemi kendim şekillendiriyorum (Ö9).

Ajans haberi diyorum. Diğer tartışma programları ve köşe yazılarında yorumlar falan oluyor ajans haberleri daha objektif (Ö1).

Benim tercihim köşe yazısı ...Çünkü orda okurken aslında bir yönlendirme de var ama bazen toplumla siyaseti biraraya getirerek yazlyorlar benim o hoşuma gidiyor (Ö5).

Ben köşe yazllar diyorum mevcut bir önceki gün yaşanan olayı ya da ilerde yaşanabilecek bir olayı yorumladı̆̆ sentezlediği için daha çok hoşuma gidiyor (Ö4).

Ben genellikle tartışma programların tercih ederim. Çünkü kendi alanında uzman olan insanların görüş beyan etmeleri o konuda demek ki bilgileri varmış deyip de ona göre bir tercih yapma imkânım oluyor (Ö3).

Ben de tartışma programlarını daha çok seviyorum. Çünkü farklı görüşler oluyor, birbirlerinin görüşlerine karşı onların savundukları şeyler oluyor ona göre ben de kendimi bir görüş çerçevesinde geliştiriyorum (Ö11).

\section{Ö̆̆retmen adaylarının haber değerlendirmeleri;}

Araştırma grubunda yer alan öğretmen adaylarının haberler ile ilgili değerlendirmeleri Tablo 2'de yer almaktadir.

Tablo 2. Sosyal Bilgiler Öğretmen Adaylarının Edindikleri Haberlerin Niteliği ve Iç̧eriği

\begin{tabular}{c|ccc|cc}
\hline & \multicolumn{3}{|c|}{ Haberin Niteliği } & \multicolumn{2}{c}{ Haberin İçeriği } \\
\hline & Söylem & Davranış & Proje & Olumlu & Olumsuz \\
\hline Toplam & $163(\% 53)$ & $73(\% 24)$ & $60(\% 20)$ & $159(\% 52)$ & $140(\% 46)$ \\
\hline
\end{tabular}

Tablo 2'ye göre öğretmen adaylarının ulaştıkları haberlerin $163(\% 53)$ 'ü bir parti başkanının ya da bir temsilcisinin sözel ifadesi, 73 (\%24)'ü bir parti başkanının ya da bir temsilcisinin davranışı, 60 (\%29)'1 ise partinin projesi hakkındadır. Öğretmen adayları bu haberlerden 159 (\%52)'unu kendi partileri açısından olumlu, $140(\% 46)$ '1nı ise kendi partileri açısından olumsuz bulmuştur.

Öğretmen adayları edindikleri haberin niteliği ile ilgili görüşlerini "Partiniz ile ilgili medyadan edindiğiniz haberin en fazla hangi nitelikte olmasını (söylem, davranış, proje) istersiniz? Neden?" sorusuna cevap olarak aşağıdaki ifadeleri yansıtmışlardır:

Benim için söylemleri önemlidir. Ben konuşmalarından feyiz aldığımı düşünüyorsam zaten kesinlikle kararımı ona göre şekillendiririm (Ö7).

Bence konuşmaları daha önemli. Çünkü konuşmalarından insanlar daha çok etkileniyor ya da o partiye daha çok oy verme eğiliminde oluyor ...(Ö11).

Söylemlerini ve projelerini. Söylemleri zaten projelerini doğrular nitelikteyse söylemleri güvenilirdir diye düşünüyorum (Ö12).

Benim için daha önce yaptıklar davranışları ile insanların kalbini kazanmışsa veya güvenini sağlamışsa bu ön plandadır.....(Ö3).

Ben daha çok davranışlarını. Çünkü insan yapamayacağı birşeyleri söyleyebiliyor. Ama davranışları gözle görülüyor olduğu için davranışları daha önemli (Ö10).

Benim için de davranışları daha çok önemli ...çünkü yaptıklartyla söyledikleri tutuyor mu diye bir tutarsızlık var mı diye bunu eleştirebilmem için (Ö8).

Benim için proje önemli.... insanlara baktı̆̆ımızda projelere daha çok önem verdikleri için vaatlere daha çok önem verdiği için bu da bende bir tık önde diğerlerine göre (Ö2).

\section{Ö̆̆retmen adaylarının habere yaklaşımları;}

Araştırma grubunda yer alan öğretmen adaylarının edindikleri haberlere bakış açıları Tablo 3'e yansitılmıştır. 


\section{BALOĞLU UĞURLU}

Tablo 3. Sosyal Bilgiler Öğretmen Adaylarının Edindikleri Haberlere Yaklaşımları

\begin{tabular}{lccc}
\hline & Evet (\%) & Hayır (\%) & \multirow{2}{*}{ Kararsızım (\%) } \\
\hline Partinle ilgili bir haber mi? & $152(50)$ & $147(48)$ & $7(2)$ \\
Sana göre haber gerçek mi? & $196(64)$ & $50(17)$ & $57(19)$ \\
Senin bu habere bir eleştirin var mı? & $186(61)$ & $110(36)$ & $10(3)$ \\
Bu haber ile ilgili bir bilgi altyapın var mı? & $147(48)$ & $140(46)$ & $19(6)$ \\
Bu habere bir yorumun ya da katkın var mı? & $175(57)$ & $112(37)$ & $19(6)$ \\
Haberi edindiğin medya, & $163(53)$ & $108(35)$ & $35(12)$ \\
senin düşüncelerine yakın bir medya mı? & &
\end{tabular}

Tablo 3'ten elde edilen verilere dayalı olarak Sosyal Bilgiler öğretmen adaylarının edindikleri haberlerden \%50'sinin (152) kendi partilerini ilgilendiren, \%48'inin (147) kendi partilerini ilgilendirmeyen haberler olduğu görülmüştür.

Öğretmen adayları için haberin kendi partileriyle ilgili olup olmadığının önemine ilişkin sözlü ifadelerden bazıları aşağıdaki gibidir:

Her haberi duyduğumda kulak kabartırım. Çünkü sadece kendi partimle ilgili haberleri izlersem ya da okursam bir süreden sonra körü körüne bir bağlllik gelişiyor ve ben burada yani Türkiye'de yalnız yaşamıyorum. Kaç milyon insan var ve o kadar da çeşitlilik var görüş açısından. En basitinden burada arkadaşlarınızla bile aranızda illaki bir çeşitlilik var. O yüzden her partiden olabildiğince haber okumaya çalışıyorum. Kendi partim öncelikli olsa da diğerlerine de kulak kabartıyorum ya da okuyorum (Ö2). .....Genel olarak da zaten başka partilerin haberlerini sürekli izlediğimi söyleyebilirim. Doğrularıma yanlışlarıma katkıda bulunduğunu düşünürüm (Ö7).

...Sonuçta bu ülkenin konusu olduğundan dolayı fark etmiyor benim için. Benim partim olsun olmasin her haberi dinlerim (Ö6).

Ben ilgilenirim. Çünkü ben mesela A partisini tutuyorsam B partisinin A partisine yönelik eleş̧tirileri de vardır elbette. Bunun doğruluğunu kontrol etmek için hangi siyasi parti olursa olsun dikkatimi çeker (Ö12).

Çok yönlü çeşitlilik önemlidir ama bir siyasi partinin görüşü çok absürdse o haberi de izlemem. Yani bana göre halkı kandirmaya yönelikse o haberi de oturup izlemem (Ö4).

.....Tamam benim savunduğum parti vardır. Onun görüşlerini yeri geldiğinde eleştiririm yeri geldiğinde olumlu bulduğum tarafları savunurum ama bazen A partisi veya $B$ partisi karşı taraf olduğu zaman baklyorum amaaaaan neyse boşver deyip de geçebiliyorum." Çünkü süreç içerisinde onların nasıl hareket ettiğini biliyorsam direk o haberi kapatmayı da biliyorum. Çünkü onların davranışlarına göre daha öncesini bildiğim için....(Ö3).

Tablo 3 ’te görüldüğü üzere, Sosyal Bilgiler öğretmen adayları edindikleri haberlerden \%64'ünün (196) gerçekliğine inanmakta, \%17'sinin (50) gerçek olmadığını düşünmekte ve \%19'unun (57) ise gerçekliğini şüpheli görmektedirler. Öğretmen adaylarının haberin gerçekliği ile ilgili yorumlamalarının bazıları aşağıdaki gibidir:

O haber kaynă̆ına göre ajansa göre değişiyor inandırıcılı̆̆ ..... ya da bu konuyla alakalı net bir bilgim varsa mesela gerçekten biliyorsam hangi yayın organı olursa olsun o habere inanırım ya da inanmam ......(Ö5).

....Eğer bilgi altyapım varsa o habere inanırım ama yoksa da kararsız kalırım (Ö13). Ben kendi kriterlerime göre düşünürüm. Kendi partime göre düşünürüm. Onlarl yapar mı yapmaz mı diye düşünürüm. Aklımda bir değerlendiririm. Ĕger ki çok arada kalırsam kesinlikle karar veremem (Ö7).

Zaten bazı haber kanallarl topluma güven vermiştir. Mesela bir haberi ortaya çıkartmıştır. Sonra haber doğru çıkmıştır. Bu yüzden medya organı sağlamsa şüphe 
etmem. Ama güvenmediğim medya organından edindiğim bir haberse ondan şüphelenirim (Ö4).

.... Her haber ajansı kendi görüşünü savunduğu için gerçekliğine güvenmem (Ö1). ...”

Tam anlamiyla güvenemiyorum. Mesela bir kanalda diyelim A partisini savunurken aynı şeyler diğer kanalda aleyhine sonuçlanabiliyor. Bu nedenle çeşitli şeylerden araştırmayı uygun buluyorum (Ö12).

Tablo 3'te Sosyal Bilgiler öğretmen adaylarının edindikleri haberlerden \%61'ini (186) eleştirdikleri, \%36'sını ise (110) eleştirmedikleri görülmektedir. Öğretmen adaylarının haberlere ilişkin eleştirileri ile ilgili yorumlamalarından bazıları şu şekildedir:

Kendi ideolojik fikrime uygunsa fazla eleştirmem ama karşıt ideolojiye aitse onu eleştiririm (Ö4).

Onun doğruluğundan emin olamazsam onu eleştiririm. Ya da benim partime laf atılmışsa bunu eleştiririm. Kendi görüşlerimi dikkate alırım (Ö10).

Haberin konusuna göre...Mesela milli bütünlügümüzü bozacaksa o an daha çok eleștiri getiririm.... Ama başka bir şey olsa sadece okurum eleştiri yapar geçerim ama çok fazla üzerinde durmam (Ö9).

Bilgi altyapıma göre eleştiririm ya da herkeste vardır bu büyük ihtimalle....(Ö3).

Haberin konusu daha önemlidir benim için. O haberin toplumu hangi yönde etkilediğine, olumlu yönde mi olumsuz yönde mi etkilediğine bakarım(Ö11).

Düşüncelerime ters bir konu olunca ya da haber olunca eleştiririm diğer durumda fazla dikkate almam (Ö6).

Tablo 3'e de yansıtıldı̆̆ı gibi, Sosyal Bilgiler öğretmen adayları edindikleri haberlerden \%57'si (175) hakkında yorum yapmışlar, \%37'si (112) hakkında ise yorum yapmamışlardır. Öğretmen adaylarının haberler ile ilgili yorumlamalarının neye bağlı olduğuna ilişkin sözlü ifadelerinin bazıları aşağıdaki gibidir:

Kendimiz önceden edindiğimiz bilgiye göre (Ö10).

Haberi tek boyutlu olmaktan çıkarmak için. Mesela haberin hem olumlu yönlerini hem olumsuz yönlerini düşünürüm (Ö11).

Bir insanin yorum yapabilmesi için bilgi birikimi gerekir....(Ö5).

Ilgi alanlarımız farklı olduğu için her habere yorum yapamıyorum. Şöyle yapamıyorum eleştirmek yorumlamaya göre biraz daha kolay. Hani bir tez ortaya atıldı̆̆ında o anda çürütebilirsin eleştiri yapabilirsin. Ama bilgi alt yapımıza göre yorumlama yapıyorsak biz ne kadar biliyoruz ne kadar okuyoruz ona göre farklıllk değişebiliyor. O yüzden her habere göre yorum yapamiyorum (Ö2).

Tablo 3'te Sosyal Bilgiler öğretmen adaylarının edindikleri haberlerin \%53 (163)'ünü kendi düşüncelerini yansıttığını hissettikleri bir medya organından, \%35'ini (108) kendi düşüncelerini yansıtmadığını düşündükleri bir medya organından, \%12'sini (35) kendi tutumları ile bağdaşıp bağdaşmadığı hakkında bir fikir sahibi olmadıkları medya organından elde ettikleri görülmektedir. Öğretmen adaylarının bir medya organının ne açıdan kendilerine yakın ya da uzak hissettikleri ile ilgili sözel ifadelerden bazıları aşağıdaki gibidir:

Bana göre bir medya organı benim partimi yeri gelince savunur yeri gelince yerer. Yani bir partiye bağımlı kalmaz. Doğruları objektif bir şekilde açılamaya çalışır (Ö10).

Medya organı ĕ̆er halkın refahını, mutluluğu, güvenliğini yani devletin uzun süre idame ettirilmesini düşünüyorsa benimserim (Ö4).

Objektif ve tarafsı olmasina bakarım...... Bazllarında objektiflik var ama nadir olarak (Ö11).

Bütün medya organlarında şu an bir tarafsızlık olmadı̆̆ için en çok benim düşüncemi hangisi savunuyorsa ben onu tercih ederim (Ö3).

Ben bugüne kadar hiçbir tarafsız medya organı görmedim. Ondan dolayı kendi partimin medya organını tercih ederim. Herkes kendi partisinin görüşünü yansitıyor (Ö6).

Objektif olursa kendime daha yakın hissederim. Objektif bir yayın organı olmadı̆̆ için kendime yakın hissettiğim bir medya organı yok (Ö1). 


\section{BALOĞLU UĞURLU}

Sosyal Bilgiler öğretmen adaylarının aktif olarak yer aldıkları medya okuryazarlı̆̆ını güçlendirme programı dâhilinde, onların seçim ile ilgili verdikleri siyasi kararlarında herhangi bir değişiklik olup olmadığına ilişkin ifadelerinin bir kısmı şu şekildedir:

Kararımı gözden geçirmedim değil ama kararım değişmedi (Ö9).

Daha önce siyasetle pek ilgilenmiyordum. Siyasi bir görüşüm de yoktu. Bu süreç içerisinde siyasi bir görüşüm oluştu (Ö11).

Benim kararım değişmedi ama üstüne biraz daha birikim oldu (Ö13).

Ben öncelikle eleş̧tirel yaklaşmaya başladım. Belki de dedim yanlış yoldayımdır. Kararımı da gözden geçirdim. Bu gözden geçirme sürecinde kendi partime daha bir sıkı devam ettim (Ö7).

....Süreçten önce zaten iki parti arasında bir çelişkim vardl. Bu süreçte yaşanan bazı olaylarla birlikte kararımı netleştirdim. Bu çalışma ile seçime daha fazla odaklandığımız için partilerin vaatlerine de odaklandık ve bu da bana yardımcı oldu (Ö4).

Sorguladım, gözden geçirdim ama kararım değişmedi (Ö1).

Sosyal Bilgiler öğretmen adaylarının aktif olarak yer aldıkları medya okuryazarlığını güçlendirme programı dâhilinde onların bu süreç ile ilgili düşüncelerinin bazıları aşağıdaki iafedelerde yer almaktadır:

...Daha çok habere ulaştık. Kendi siyasi görüşümüze ters olan medya organlarından da bilgi edindik (Ö12).

Ben olaylara sadece kendi penceremden baklyordum. Bunlarl yaptlktan sonra farklı kişilerin farklı pencerelerinden bakabildiğimi gördüm. Yani bana katkısı oldu (Ö9).

Diğer partileri daha iyi tanıma firsatı buldum .... Bence çok güzel bir şey oldu (Ö6).

Bu çalışmada samimi olma ihtiyacı duydum....Bu süreç bayağ işe yaradı bende (Ö10).

Bu sürecin çok yönlü düşünme yeteneğimizi geliştirdiğini düşünüyorum. Çünkü birçok görüş vardı. Kendi siyasi görüşümle o görüşleri karşılaştırma firsatı buldum (Ö4).

Benim bakış açımı her yönüyle genişlettiğini söyleyebilirim...(Ö2).

Bence iyiydi. Ben sadece kendi düşüncemi savunuyordum ya da eleştiriyordum. Bu süreçte şunu farkettim. Herkesin kendine göre bir düşüncesi var. Benim savunduğum partinin de yanlış tarafları eleştirilecek tarafları var. Bunu farkettim ve bence olumluydu (Ö3).

Düşünce yapımızı farkl görüşlere açık hale getirdi bence bu süreç (Ö11).

Bütün partileri daha olumlu olumsuz yönleriyle görmemi sağladı (Ö8).

\section{Tartışma ve Sonuç}

Günümüzde kitle iletişim araçlarının hayatın vazgeçilmez bir parçası olmasının en önemli nedenlerinden biri, medya ve siyasetin bütünleşik bir yapıya sahip olmasıdır. Toplumdaki bireylerin siyasal yaşamdan uzak olmaları mümkün değildir. Bu manâda, bireylerin kendi siyasi düşünce yapılarını ve hayatlarını şekillendirmede en aktif olarak kullandıkları araçlardan biri medyadır. $\mathrm{Bu}$ araştırmada, Sosyal Bilgiler öğretmen adaylarının medyayı kendi siyasal düşüncelerini geliştirmede bir araç olarak kullanmaları daha sistematik bir süreç halinde gerçekleştirilmiş ve çalışma programı sonrasında çalışma grubundan elde edilen veriler sayısal ve nitel olarak değerlendirilmiştir.

Araştırma sonuçlarından en önemlilerinden biri, öğretmen adaylarının seçim odaklı siyasi gündemden edindikleri haberlerin en fazla gazete ve internet kanalı ile gerçekleşmiş olmasıdır. Ancak, bu araştırma sırasında öğretmen adaylarına televizyon imkânı sağlanamadığı için öğretmen adayları televizyon haberlerini de internetten takip etmek durumunda kalmışlar ancak bu uygulama onlar için kısıtlı olmuştur. Bu nedenle öğretmen adayları çalışma sürecinde her ne kadar erişim olarak internet ve gazeteyi tercih etseler de, çalışma sonrasında yapılan görüşmede öğretmen adaylarının televizyona bakış açılarının da oldukça olumlu olduğu görülmektedir. Nitekim Baltacı ve Eke (2012)'nin yaptığı araştırma da bu araştırmadaki öğretmen adaylarının sözel ifadelerini destekler niteliktedir. Araştırmacı, kendi çalışmasında yer alan araştırma grubunun \%50'sinin siyasi davranışlarında televizyondan etkilendikleri yönünde 
bilgi verdiklerini ifade etmektedir. Araştırmada, televizyon, internet ve gazetenin en çok tercih edilen araçlar olması, bu medya organlarının yaygınlığı ve kullanım kolaylığı ile ilgilidir. Öğretmen adayları özellikle de televizyon ve internetin ulaşım ve kullanım kolaylığına vurgu yapmışlardır. Televizyon ve internetin kitlesel etkileri arasında yer alan bu sebepler, yapılan diğer araştırmalarda da belirtilmektedir (Aksaçlıoğlu ve Yılmaz, 2007; Barkhuus, 2009; Bayraktaroğlu ve Uğur, 2011; Güllüoğlu, 2012; Güzel, 2006; MEB-Eğitim Araştırma Geliştirme Dairesi Başkanlığı (EARGED), 2008; Karaman, 2010; Lennon, Smith ve Byford, 2014; Sarsar, Başbay ve Başbay, 2015; Şamlı ve Konak, 2011; Şener, 2009; Tubella, 2004; Yurdigül ve Zinderen, 2012).

Öğretmen adaylarının siyasi haberleri edindikleri medya ürünü olarak en fazla tercihlerinin ajans haberi yönünde olduğu görülmektedir. Yapılan görüşmede Sosyal Bilgiler ögretmen adayları tarafından bu durumun en önemli nedeni olarak ajans haberlerinin daha objektif ve tarafsız olduğu gösterilmektedir. Öğretmen adaylarının bu tespiti Gökgücü (2007) tarafından da doğrulanmaktadır. Araştırmacı, haber ajanslarının haberleri satabilmek için çok sayıda ve farklı görüşte yayın kuruluşlarına seslenmeleri gerektiğini ifade etmektedir. Bu nedenle de ajanslar yazdıkları haberde yorumdan çok olguları gözetmekte ve her siyasal görüşe ilişkin haberi birini diğerine tercih etmeden yer vermektedirler. Böylece nesnellik ve tarafsızlığ 1 kural olarak benimsemişlerdir. Araştırma grubunun edindiği haberlerden 1/4’ünün ise köşe yazısını tercih ettikleri görülmüştür. Bu durum öğretmen adayları tarafından kendilerine özgü bir düşünsel yapı olarak yorumlansa da bir gerçeği ortaya koymakta fayda vardır. Seçim dönemlerinde köşe yazarlarının en fazla işledikleri tema siyasal seçimler olarak karşımıza çıkmaktadır (Alver, 2011; Köker ve Kejanlıŏlu, 2004).

Öğretmen adaylarının seçimlerle ilgili edindikleri haberlerin nitelik olarak en fazla bir parti lideri veya temsilcisinin söylemi olduğu görülmektedir. Öğretmen adayları, parti temsilcilerinin söylemlerinin bireysel olarak kendilerini ya da kitlesel anlamda toplumları etkileyebilecek bir özellik olduğuna vurgu yapmışlardır. Alanyazında, Saygılı (2014)'nın seçim sürecinde siyasi parti liderlerinin, siyasi rakiplerine ilişkin ürettikleri ve kullandıkları söylemler aracılığıyla seçmenlerin algılamalarını yönlendirdikleri ve etkilemek istedikleri yönündeki ifadeleri bu durumla ilişkilendirilebilir niteliktedir. Güngör (2014) de siyasetin söylemsel bir etkinlik olmasının, bununla birlikte söz ve davranışın bütünleştirilmesi ile siyasi partiler arasındaki söylem farklarının ve bu söylemlerin taşıyıcısı olan siyasal dillerin ortaya koyulmasının seçim döneminde alınan kararlarda etkili olabildiği ile ilgili görüşü, bu duruma yine açıklık getirebilecek ifadeler olarak gösterilebilir. İnal (2010) ise medyanın, siyasal yapı ve siyasal kültürü yansıtan kamusal tartışmaların taşıyıcısı ve siyasal söylemlerin kurulduğu ortam olduğundan söz etmektedir.

Öğretmen adaylarının edindikleri haberlerle ilgili kendi partileri açısından bir seçicilik

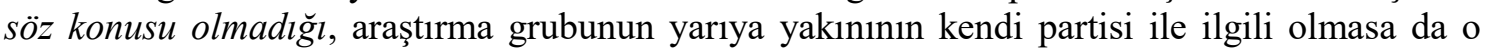
haberle ilgilendiği görülmektedir. Sayısal verileri destekleyen öğretmen adaylarının sözel ifadeleri, Kurt ve Kürüm (2010)'ün kendi araştırmasında açılımını gerçekleştirdiği eleştirel düşünen medya okuryazarı kavramı ile bağdaştırılabilir. Şöyle ki; eleştirel düşünen bir medya okuryazarı; medyadan gelen hiçbir bilgiye kendini kapalı tutmaz iken, edindiği bilginin bir başkasının bakış açısıyla oluşturulup, her gerçeği yansıtmayabileceği, eksik yansımaların olabileceği ya da manipülasyonların yaşanabileceği ihtimalleri üzerinde durur. Bu durumda da birey, medyadan aldığı mesajı kendi düşünsel süzgecinden geçirerek en doğru bir şekilde karar vermeye eğilimli olur.

Araştırmadan elde edilen bir diğer sonuç, öğretmen adaylarının edindikleri siyasi haberin gerçekliği ile ilgili düşünceleridir. Öğretmen adaylar1 edindikleri haberlerin \%64'ünü gerçek olarak algılamışlardır. Ögretmen adayları bu durumu farklı bakış açıları ile yansıtırken, kimi haber ajanslarının niteliğine, kimi kendi bilgi altyapısına, kimisi de kendi düşünsel yapısına vurgu yapmıştır. Alanyazında ise haberin gerçekliği konusunda Girgin (2005)'in ifadelerine yer vermek gerekir. Araştırmacıya göre haberlerde tam bir nesnellikten söz etmek mümkün değildir. Her birey, olayları kendi inançları, davranışları ve değerler bütünü çerçevesinde görme ve algılama eğilimindedir. Bu nedenle gerçek ancak "göreceli" olabilir. 


\section{BALOĞLU UĞURLU}

Toplumun algılaması ile ilgili Gönenç (2004) ise medyada tasarımlanmış iletilerin mevcudiyetinden ve toplumun bu tarz iletilere çok alışmış olduğundan gerçek haberin bu kurgu içinde yok olup gittiğini fark edemediğinden söz etmektedir. Gökgücü (2007) ise hem toplum hem de medya açısından olayı irdelemeiş ve "medyanın nesnel biçimde yansıttı̆̆ını iddia ettiği 'gerçeklik', o toplumda o dönem başat olan gerçeklik kurgularının yeniden üretilmiş biçimi olabilir ancak'(sf.38) ifadesini kullanmıştır. Yapar Gönenç (2002)'in bu durumla ilgili ifadeleri ise haberin birebir gerçek değil gerçeğin bir kurgusu olduğu, bu nedenle de medya organının olayı nasıl kurguladığı ya da hikâye ettiğinin önemli olduğu şeklindedir. Araştırmacı, kendi çalışmasında Kahraman'ın da ifadelerine yer vererek haberin her an ve yeniden kurgulanabileceği, olayı izleyenin veya aktaranın bakış açısı ve hazırlık durumuna göre her an haberin anlatım seyri ve verilmek istenen sonucun değişebileceği yorumunu yansıtmaktadır. Edgar(1998)'ın da haberin tarafsızlığı ile ilgili yorumlamaları alanyazında yer almaktadır. Araştırmaciya göre, bir haberin nesnel olabilmesi için o habere konu olan eylemin hiç bozulmayacak şekilde yorumlanması gerekmekte, ancak en yansız yaklaşım bile gerçeği saptırmak zorunda kalmaktadır (Akt. Duruoğlu, 2003). Büyükkanber ve Makarac1 (2015) ise kendi araştırmasında aynen şu ifadeleri kullanmıştır: "Objektif, değer yargıları taşımayan medya mesajları olmaz. Her haber bir yorumdur, her iletide hangi kısım öne çıkarılmışsa o yönde bir etkileme/yönlendirme vardır. Medya mesajları onu üretenlerin veya üretilmesini isteyenlerin inançlarını, değerlerini, görüşlerini ve önyargılarını içerir."(sf.21). Gönenç (2004), medya organlarının haberlerini hazırlamada kimi zaman gösterdikleri özensizliğin olayın gerçek doğrusunun ne olduğunu anlamamızı engellediğini, bu durumun medya kuruluşları için önemli bir zaaf olduğunu yansıtmaktadır. Araştırmacı, medya kuruluşlarının sistemsel işlevselliğin arac1 durumuna geldikleri ve bu nedenle medya kuruluşlarında yayınlanan haberlerin bu sistemsel işlevselliğin gerektirdiği biçimde ve yayın organının genel politikasına uygun olarak oluşturulduğundan dolayı bu sorunun yaşandığını ifade etmektedir. Bütün bu medyadaki gerçeklikle ilgili düşünce ve görüşler sonuçta medyanın güvenilirliğinin sorgulanmasına neden olmaktadır. Nitekim Baloğlu Uğurlu (2015) yaptığı araştırmada Sosyal Bilgiler öğretmen adaylarının medyaya olan güvenlerinin düşük düzeyde olduğu tespitinde bulunmuştur.

Araştırmanın bir diğer sonucu, öğretmen adaylarının edindikleri seçimlerle ilgili haberlerin yarıdan fazlasına eleştiri ve yorumlama getirmeleridir. Yapılan görüşmede öğretmen adayları her ne kadar yaptıkları eleştiri ve özellikle de yorumlamaları kendi bilgi altyapıları ile ilişkilendirseler de öğretmen adaylarının bilgi altyapıları olduğu için eleştiri ve yorumlama yapanların oranı ile bilgi altyapıları olmadığı halde eleştiri ve yorumlama yapanların oranı yarı yarıyadır. Oysa yapılan istatistiksel analizlerde öğretmen adaylarının habere getirdikleri eleştiri ve yorumlamalar ile onların haberi edindikleri medya türü arasında bir bağlantı kurulabilmiştir. Nitekim öğretmen adaylarının okudukları gazete ve internet haberlerinin 2/3'üne; televizyon haberlerinin ise $1 / 3$ 'üne eleştiri ve yorum yapmışlardır. Bu durum yazılı haberin statik bir yapıya sahip olmasından, haberin istenildiği zamanda ve koşulda tüketilebilmesinden kaynaklanmaktadır. Haber okuyucunun yorumuna açıktır. Haber okuyucusu sözcüklere ve satırlara farklı anlamlar yükleyebilir ve böylece haberi eleştirebilme imkânı bulabilmektedir (Yurdigül ve Zinderen, 2012). Oysa bilgi akışının hızlı olduğu, dinamik bir yapıya sahip olan televizyon ve radyo gibi araçların bu etkisinin daha düşük düzeyde kalacağı açıktır. Araştırmada, öğretmen adaylarının eleştiri getirdikleri haberler ile ilgili kendi ideolojik düşüncelerini ön plana çıkardıkları ifadeler de yer almaktadır. Bu durumda öğretmen adaylarının haberlere getirdikleri eleştiriler ve yorumlamalar haberi edindikleri medya türü ile de ilişkilendirilebilir. Öğretmen adaylarına yöneltilen "Haberi edindiğin medya organı senin düşüncelerine yakın bir medya mı?" sorusuna \%90'a yakınının "evet" ya da "hayır" diye cevap vermesi mevcut medya organlarının taraflılığını kabul ettikleri anlamına gelir. Bu sonuç alanyazında da sıklıkla tartışılmaktadır. Güneş (2014)'in içerik analizi yöntemi ile gerçekleştirdiği çalışmasında 2014 yerel seçimlerinde bir basın organının kendisine rakip gördüğü diğer bir basın unsuruna göre medyanın imajını olumsuz bir algıya dönüştürme çabasında olduğu görülmüştür. Bu durumun medya takipçilerine de yanlı bir şekilde yansıması kaçınılmazdır. Nitekim Yılmaz (2013) KKTC'de yaptığı çalışmasında, araştırma grubunun 
\%63'ünün medya organlarını "taraflı" olarak gördükleri sonucuna varmıştır. Öğretmen adaylarının, tercih ettikleri medya organının kendilerine ne açıdan yakın hissettikleri ile ilgili soruya ise birçoğunun kendi ideolojik düşüncelerine yakın olan medya organından hoşlandıkları sonucu çıkmıştır. Bu sonuçta aslında bir paradoks vardır. Şöyle ki; bireyler açısından tercih edilen medya gerçekten birey tarafından "kendisine yakın hissettiği" medya mıdır yoksa "kendisi etki altında bırakılan" medya mı? Alanyazında Kaplan ve Ertürk (2012)'ün ifadeleri bu duruma açıklık getirmeye yarayabilir. Araştırmacıya göre, medya insanlar üzerinde egemenliğini sürdürmekte, kamu yararını kamu merakına dönüştürmektedir. Böylece medya kamu yararına malzeme sağlamaz, kamu zihnini kontrol etmeye çalışır. Bir başka deyişle medya kamuya "benim gibi düşün!” demeye başlar. Bu tutum medyanın kendi düşüncelerini topluma yaymasının en açık göstergesidir. Büyükkanber ve Makaracı (2015) ise bireylerin sıklıkla takip ettikleri ve "kendilerinden gördükleri" medyanın sakıncalarına değinmektedir. Araştırmacı, takip etmedikleri medyanın zaten bireyleri yönlendiremeyeceğini, buna karşın bireylerin kendilerine yakın hissettikleri medyanın yayınlarına eleştirel bir gözle bakmayıp, tamamen "pasif alıcı" konumunda vermek istedikleri mesajları algılayıp kendi fikirlerine ters bile gelse savunur hale geleceklerini ifade etmektedir. Bu durumda bireyin yapması gereken, sadece karşıt medya olarak gördükleri organlardan gelen iletilere değil, kendine yakın hissettikleri medyadan gelen iletilere karşı da eleştirel olmasıdır.

Son olarak, araştırmada, öğretmen adaylarının bu süreç ile ilgili düşünceleri ve bu süreçte kendi siyasi kararlarında herhangi bir değişiklik olup olmadığ öğrenilmek istendi. Öğretmen adaylarının süreci kendileri açısından olumlu değerlendirmeleri ve her ne kadar siyasi kararlarında bir değişiklik söz konusu olmamışsa da öğretmen adaylarının neredeyse tamamına yakının siyasi kararlarını düşünsel süzgeçlerinden geçirmiş olmaları elde edilen en önemli sonuçlar olmuştur. Araştırmada medya okuryazarlığı programının gerçekleştirmek istediği hedef de budur. Medyadan ulaşan mesajlar kişileri sadece bilgilendirmekle kalmayıp, onların değer yargılarını, tavırlarını, inançlarını ve çeşitli yönleriyle yaşama bakış açılarını etkiliyorsa ve hatta yeniden şekillendiriyorsa medya okuryazarlığı gerçekleşiyor demektir (Önal, 2007). Bu durumda yapılması gereken, medya okuryazarlığını sistematik bir şekilde gerçekleştirmeye yönelik olarak, bireylerin ilkokuldan başlayarak yükseköğretimde devam edecek şekilde bilinçlendirmek, bu bilinçlendirme kapsamında çeşitli imkânlar sağlamak ve onların çoklu bakış açılarını geliştirerek duyuşsal anlamda kendilerine olan özgüvenlerini artıracak faaliyetleri gerçekleştirmelerini sağlamaktır.

\section{Kaynaklar}

Akdağ, M. (2014). Medya ve siyaset üzerine, Medi@Ware Projesi. 31 Ağustos 2015 tarihinde $\mathrm{http} / / /$ mediaware.erciyes.edu.tr/tr/medya_ve_siyaset_uzerine.pdf adresinden alınmıştır.

Aksaçlıŏlu, A. G. ve Yılmaz, B. (2007). Öğrencilerin televizyon izlemeleri ve bilgisayar kullanmalarının okuma alışkanlıkları üzerine etkisi, Türk Kütüphaneciliği, 21 (1), 328.

Altun, A. (2009). 21. Yüzyıl Vatandaşlığı İçin Gerekli Bir Beceri Olarak Medya Okuryazarlığı: UNESCO, AB ve Türkiye Örnekleri. I. Uluslararası Avrupa Birliği, Demokrasi, Vatandaşlık ve Vatandaşlık Eğitimi Sempozyumu Bildiri Kitabı. Ankara: Pegem Akademi, 9-17.

Alver, F. (2011). Basında Siyasal Liderlerin ve Köşe Yazarlarının Sosyal Haklara İlişkin İletilerinin Analizi, Sosyal Haklar Uluslararast Sempozyumu III, İstanbul, 25-26 Ekim 2011, 289-338.

Apospori, E., Avlonitis G., \& Zisouli, M. (2010). Political culture and perception of political marketing tools: A cross-generational comparison, Journal of Political Marketing, 9, $111-134$.

Arklan, Ü. ve Karakoç, E. (2013). Medyanın genel ve siyasal gündeme ilişkin bilgi edinme aracı olarak kullanımı: Görgül bir araştırma, Türkiyat Araştırmaları Dergisi, 33, 325-363. 


\section{BALOĞLU UĞURLU}

Arslan, A. (2002). Medyanın birey, toplum ve kültür üzerine etkileri, Uluslararası İnsan Bilimleri Dergisi, 1 (1), 1-12.

Baltacı, C. ve Eke, E. (2012). Siyasal propaganda araçlarının seçmen davranışı üzerindeki etkisine yönelik seçmen algısı: Isparta örnek olayı, Uluslararası Alanya İşletme Fakültesi Dergisi, 4 (1), 115-126.

Baloğlu Uğurlu, N. (2015). Sosyal Bilgiler öğretmen adaylarının siyasi kararlarında medyanın etkililiği, Hasan Ali Yücel Ĕgitim Fakültesi Dergisi, 12-2, (24), 99-115.

Barkhuus, L. (2009). Television on the Internet: New Practices, New Viewers. CHI 2009, April 4 - 9, 2009, pp. 2479-2488. ACM Press. Retrieved November 13, 2015 from http://www.barkhu.us/television-altchi.pdf.

Bayraktaroğlu, A. M. ve Uğur, U. (2011). Televizyon haberciliğinde magazinleşme olgusu, Süleyman Demirel Üniversitesi Güzel Sanatlar Fakültesi Hakemli Dergisi, 7, 3-47.

Bilici, İ. E. (2012). Medya eğitimi: Bir gözden geçirme zamanı (çeviri makale), Akademia, 2 (4), 76-82.

Bilici, İ. E. (2014). Medya okuryazarlı̆̆ı ve eğitimi, Ankara: Nobel Yayın Dağıtım.

Büyükkanber, C. ve Makarac1, M. (2015). Eleştirel Düşünme İzdüşümü Olarak Medya Okuryazarlığı, 1. Uluslararası Kritik ve Analitik Düşünme Sempozyumu, Sakarya: Sakarya Üniversitesi, 10 Nisan 2015, 16-23.

Çağlar İ. ve Özkır Y. (2015). Türkiye'de siyasal iletişim 2007-2015, SETA Yayınları, İstanbul: Turkuvaz Yayıncilik.

Çebi, M. S. (2002). Günümüzde siyasetin medyada inşası ve sunumu üzerine bazı dikkatler, Iletişim, 14, 1-33.

Çetinkaya, S. (2008). Bilinçli medya kullanıcıları yaratma sürecinde medya okuryazarlı̆̆ının önemi, Yayımlanmamış yüksek lisans tezi, Ankara: Ankara Üniversitesi Sosyal Bilimler Enstitüsü.

Çokluk, Ö., Yılmaz, K. ve Oğuz, E. (2011). Nitel bir görüşme yöntemi: Odak grup görüşmesi, Kuramsal Eğitimbilim, 4 (1), 95-107.

Dilber, F. (2012). Siyasal toplumsallaşmada seçmenlerin siyasal tercihine sosyal unsurların etkisi: Karaman ili seçmenleri üzerine bir alan araştırması, Akademik Bakış Dergisi, $32,1-19$.

Duruoğlu, T. (2003). Haber yapmada ideoloji etkeni: 11 Eylül terör olayı örneği üzerine bir inceleme, Yayımlanmamış yüksek lisans tezi, Ankara: Ankara Üniversitesi Sosyal Bilimler Enstitüsü.

Gezgin, S. (2006) Medya ve Demokrasi, Medya Merceğinde Almanya ve Türkiye Semineri, 20. Alman-Türk Gazeteciler Semineri Bildiri Kitabı, s. 165-176. 26 Ekim 2015 tarihinde http://www.konrad.org.tr/Medya\%20Mercek/19gezgin.pdf adresinden alınmıştır.

Girgin, A. (2005). Haber yazmak (3. Bask1), İstanbul: Der Yayınlar1.

Gökgücü, I. (2007). Siyasal parti haberlerinde "tarafsızlık" kavramı, Yayımlanmamış yüksek lisans tezi, Ankara: Ankara Üniversitesi Sosyal Bilimler Enstitüsü.

Gönenç, E. Ö. (2004). Haberde Çarpıtma, II. Uluslararası İletişim Sempozyumu, İstanbul, Mart 2004, 2(1), 53-64.

Güllüoğlu, Ö. (2012). Bir kitle iletişim aracı olarak televizyonun popüler kültür ürünlerini benimsetme ve yayma işlevi üzerine bir değerlendirme, Global Media Journal Turkish Edition, 2 (4), 64-86.

Güngör, S. (2014). Türk siyasetinde dil kullanımı: Siyasal parti liderlerinin TBMM grup konuşmalarında siyasal söylem analizi, Yasama Dergisi, 26, 65-88.

Güneş, A. (2014). Gündem belirleme teorisi bağlamında 30 Mart 2014 yerel seçimlerinin basında sunumu: AKP ve CHP örneği, The Turkish Online Journal of Design, Art and Communication-TOJDAC, 4 (2), 1-15.

Güzel, M. (2006). Küreselleşme, internet ve gençlik kültürü, Küresel İletişim Dergisi, 1, 1-16.

İnal, A. (2010). Haber medyası ve seçim kampanyaları, Bülent Çaplı ve Hakan Tuncel (Ed.), Televizyon Haberciliğinde Etik Sorunlar içinde (s.251-266). Ankara: Fersa Matbaacilık. 
Kaplan, K. ve Ertürk, E. (2012). Dijital çă̆ ve bireyin ideolojik aygitları, The Turkish Online Journal of Design, Art and Communication - TOJDAC, 2 (4), 7-12.

Karaman, M. K. (2010). Öğretmen adaylarının TV ve internet teknolojilerini kullanma amaç ve beklentilerinin medya okuryazarlığ bağlamında değerlendirilmesi, Uşak Üniversitesi Sosyal Bilimler Dergisi, 3 (2), 51-62.

Kenterelidou, C. (2005). Public Political Communication and Media. The case of contemporary Greece, The 2nd LSE PhD Symposium on Modern Greece, "Current Social Science Research on Greece, 10 June 2005, LSE University\&Hellenic Observatory, Greece Retrieved November 30, 2015 from http://www.lse.ac.uk/europeanInstitute/research/hellenicObservatory/pdf/2nd_Symp osium/Clio_Kenterelidou_paper.pdf.

Köker, E. ve Kejanlığlu, B. (2004). 2002 seçim kampanyalarında ulusal basın, İletişim Araştırmaları, 2 (1), 39-70.

Kurt, A. A. ve Kürüm D. (2010). Medya okuryazarlığı ve eleştirel düşünme arasındaki ilişki: Kavramsal bir bakış, Mehmet Akif Ersoy Üniversitesi Sosyal Bilimler Enstitüsü Dergisi, 2 (2), 20-34.

Lennon, S., Smith, A. M., \& Byford, J. M. (2014). High school social studies teachers' perceptions of news media, National Forum of Teacher Education Journal, 24 (3), 117.

MEB (Millî Eğitim Bakanlığı) EARGED (Eğitimi Araştırma ve Geliştirme Dairesi Başkanlığı), (2008). Öğrencilerin televizyon izleme alışkanlıkları, Ankara: Millî Eğitim Bakanlığı Kaynak Kitaplar Dizisi.

MEB (Millî Eğitim Bakanlığı), (2005). İlköğretim sosyal bilgiler dersi öğretim programı ve kılavuzu, Ankara: Devlet Kitapları Müdürlüğü.

Önal, İ. (2007). Medya okuryazarlı̆̆ı: Kütüphanelerde yeni çalışma alanı, Türk Kütüphaneciliği, 21 (3), 335-359.

Sarsar, F., Başbay, M ve Başbay, A. (2015). Öğrenme-öğretme sürecinde sosyal medya kullanım1, Mersin Üniversitesi Eğitim Fakültesi Dergisi, 11 (2), 418-431. doi.org/ 10.17860/efd.98783

Saygıl1, R. (2014). Siyasi lider söylemlerinin vatandaşların siyasi parti tercihi üzerindeki olası etkileri: 2011 genel seçimlerine yönelik bir alan araştırması, Selçuk Üniversitesi Sosyal Bilimler Enstitüsü Dergisi, 32, 103-113.

Şamlı, R. ve Konak, E. (2011). Tedbir mi, Kısıtlama mı? İnternet Sansürü Hakkında Bir Araştırma, Akademik Biliş̧im Konferansları, Malatya, 2-4 Şubat 2011.

Şener, G. (2009) Türkiye'de Facebook Kullanımı Araştırması, XIV. Türkiye'de Internet Konferansl, İstanbul: İstanbul Bilgi Üniversitesi, 12-13 Aralık 2009, 1-8.

Thoman, E., Jolls, T., \& Center for Media Literacy. (2003). Literacy for the 21st century: An overview \& orientation guide to media literacy education, Los Angeles: Center for Media Literacy. Retrieved in December 7, 2015 from http://www.medialit.org/sites/default/files/01_MLKorientation.pdf.

Tornero, J. M. P., \& Varis, T. (2010). Media literacy and new humanism, Russia: UNESCO Institute for Information Technologies in Education.

Tubella, I. (2004) Television, the Internet, and the Construction of Identity. En Castells, M. \& Elgar, E. The Network Society: A Cross -cultural perspective. UK. Cheltenham. Retrieved in November 26, 2015 from http://cies.iscte.pt/linhas/linha2/sociedade_rede/pr_htdocs_network/apps/immatubella. pdf.

Üskül, Z. (1993). Yeni Bir Demokrasi Anlayışı-Yerel Demokrasi. Anayasa Yargısı, Ankara, C: 10, $3.333-344 . \quad 13 \quad$ Kasim $2015 \quad$ tarihinde http://www.anayasa.gov.tr/files/pdf/anayasa_yargisi/anyarg10/zuskul.pdf adresinden alınmıştır.

Yapar Gönenç, A. (2002). Medya ve haber, İletişim Fakültesi Dergisi, 14, 77-89. 


\section{BALOĞLU UĞURLU}

Yazıcı, K. (2014). Medya ve değerler, Refik Turan ve Kadir Ulusoy (Ed.), Farklı Yönleriyle Değerler Ĕ̈itimi içinde (s. 142-189). Ankara: Pegem Akademi.

Yıldırım, A. ve Şimşek H. (2006). Sosyal bilimlerde nitel araştırma yöntemleri (6. Baskı), Ankara: Seçkin Yayıncılık.

Yılmaz, M. (2013). Medya ve siyaset ilişkilerinin kamuoyu üzerindeki etkileri: KKTC örneği, Insan ve Toplum Bilimleri Araştırmaları Dergisi, 2 (2), 230-252.

Yurdigül, Y. ve Zinderen, İ. E. (2012). Yeni medyada haber dili (Ayşe Paşalı olayı üzerinden geleneksel medya ve internet haberciliği karşılaştırması), The Turkish Online Journal of Design, Art and Communication - TOJDAC, 2 (3), 81-91.

\section{Extended Abstract}

\section{Introduction}

Technological developments have affected democratic behaviors. In other words, people use the mass media to reflect their democratic perspectives in different forms. Election times are good examples creates to use media which a communication between politicians and society. Political parties enable campaign strategists to target messages to selected voter segments through media. Meanwhile, data show that the public that is exposed to more information can learn can learn quite a lot, quite rapidly from television news, party web sites, and newspapers can decide for voting easily to this way. However, individuals have paradox related with media sometimes. Especially, media's reliability is very important for people. If they do not trust they aren't affected by its messages a lot. Also, in the literature, many academic works emphasized that media have to be careful to deliver its messages to public. Besides, people should use media consciously (deliberatively). Media literacy which is a popular concept recently which is a popular concept recently, would be helping for people to use media best. Media literacy is related with some fields, such as critical thinking and an improvement of the capacities of selection and information processing; the problem-solving capacity; improvements in expressive, communicative and interactive capacities and civic participation and active citizenship. These skills are also important for Social Studies Education which keeps at the forefront to educate active citizens in the society. Therefore, we must give weight to media literacy and we must educate preservice Social Studies teachers who bring our children to society about this issue. This study, to reach this purpose, is configured with with preservice Social Studies teachers' applications which show what level they internalized to media literacy, and their perspectives about the using media were evaluated. The study was conducted especially during election time. That's because media's effectiveness was tested (evaluated) on the preservice Social Studies teachers' political decisions and their perspectives to political parties.

\section{Method}

This study which was designed as mixed method research was conducted with thirteen preservice Social Studies teachers who are students in Nigde University, Faculty of Education in the fall semester of the 2015-2016 academic year. Mixed method research includes aspect of both quantitave and qualitative research methods. In the study, quantitative data were collected with an evaluated form. Preservice Social Studies teachers filled out a form about getting each news. And then, researcher analyzed these forms with descriptive statistical analysis methods. Also, focus group discussions and semi-structured interviews as a qualitative research method were applied to research group. Because focus group discussions do not have to be generalized, teacher candidates'statements were conveyed to paper exactly.

\section{Result and Discussion}

In this study, preservice Social Studies teachers showed behaviours as an active media literate. One of the study results was that teacher candidates prefered the newspaper, internet and 
television mostly. Teacher candidates stated both accessibility and ease of use to this tools.In the literature, aspect of this tools were emphasized in many papers ((Aksaçlioğlu ve Yılmaz (2007) ; Barkhuus (2009) ; Bayraktaroğlu ve Uğur (2011) ; Güllüoğlu, (2012) ; Güzel (2006); MEB-EARGED, (2008) ; Karaman (2010) ; Lennon, Smith \& Byford, (2014) ; Sarsar, Başbay ve Başbay, (2015) ; Şamlı ve Konak (2011) ; Şener (2009) ; Tubella (2004) ; Yurdigül ve Zinderen (2012).

Teacher candidates got news from agency mostly. According to them, agency news are more objective and impartial. This determination is supported by the literature. News agencies that sell their news to many media organizations have to transfer news directly no comment (Gökgücü, 2007).

Teacher candidates preferred to get news about political party leader's or political party representatives' statements. They said that political party leader's or political party representatives' statements more effective on the public than theirs' behaviours or projects. In the literature, Saygil1 (2014) stated that in the election times, political party leaders' effort to influence people through bad statements about opposition parties. Thus, they think to win election. Also, Güngör (2014) emphasized political party leaders or political party representatives' both statements and behaviors are important to impress people in the election times.

Teacher candidates were not selective according to their parties. Meanwhile, they got both theirs party's news and opposition parties' news. This attitude of teacher candidates comply with media literate perception. Media literate doesn't keep himself/herself off to any news. He/she just thinks critical about news and tries to see manipulations or the lack of news (Kurt and Kürüm).

Teacher candidates' opinion about the reality of the news is another result this study. More than half of teacher candidates stated that they acquaired the real news from media. They based these on quality of news agencies, their acknowledge infrastructure or intellectual structure. However, in the literature, there are many suspicions about the reality of news (Gönenç (2004), Gökgücü (2007), Yapar Gönenç (2002), Duruoğlu (2003), Büyükkanber ve Makarac1 (2015). Common to all is that news is not to be real exactly. It is edited by media proprietors. Thus, it often loses its realities and it is seen subjective.

Teacher candidates bring criticism and comment on more than half of news which was got from media. These criticism and comments were related with media tools. They brought criticism and commented two thirds of newspaper news or internet news and just one thirds of television news. Reason of this result can be explained that written news have a static structure. The reader can easily comment on or bring to criticism to such news (Yurdigül ve Zinderen, 2012). However, television or radio information flow is faster. Therefore, their effect is low on the people according with critical thinking or comment. At the same time, teacher candidates' criticism and comments can be associated with media organizations. Almost all of the teacher candidates see media organizations as "close or far away". Also this situation is supported with academic works. Researchers who work in this field accept that individuals who select any media organizations see these organizations very close their political thinking. However, researchers ask the question if they really choose these media organizations or they are under these organizations' influence? They stated that second possibility is higher (Kaplan ve Ertürk (2012); Büyükkanber ve Makarac1 (2015). At this point, media literacy is gaining important again.

Finally, the researcher wanted preservice students to evaluate the research process. Teacher candidates stated that the process was positive. They said that they did not change their politicial decisions but they reviewed them. This result was important for the research. If messages from the media influence and also cause revise individuals' judgement, attitude, belief, faith or perspectives to life, it means media literacy takes place. In this case, individuals should be educated about the media from primary school to university. In this education process, various facilities should be provided for students and they should be organized various activities which will increase their self-confidence. 